\title{
Sekülerlikten Radikalleşmeye: İsrail'in Kurucu Felsefesinde Konstrüktivist Dönüşüm
}

\author{
Haydar Oruç*
}

Öz

$\mathrm{Bu}$ makalede İsrail devletinin kuruluş felsefesinde yer alan; "seküler", "sosyalist Siyonizm değerlerine bağlı", "çoğulcu ve çok kültürlü”, "barışcıl", "demokratik bir cumhuriyet" kimliğinin nasıl olup ta "Yahudi Devleti", "dindar Siyonizm değerlerine bağl1", "muhafazakar", "tek millet ve tek kültür", "bölgesel güç”, "nükleer güç”, "güvenlikçi”, "savaşçı”, "tavizsiz” bir devlet haline dönüştüğü konu edilmektedir. Nicholas Onuf tarafindan ortaya atılan ve Alexander Wendt tarafından geliştirilerek mevcut haline getirilen inşacılık (constructivism) anlayışının yapı ve aktör arasındaki birbirini yeniden inşa etme prensibinden yola çıkılarak, İsrail devleti ve toplumunun kuruluşundan günümüze "norm", "kültür" ve "kimlik" bağlamında nasıl dönüştüğü bütünsel (holistic) sosyal inşacı yaklaşımla açıklanmaya çalışılmaktadır.

Anahtar Kelimeler: Sosyalist Siyonizm, Kurucu Felsefe, İnşacılık, YapıAktör İlişkisi, Bütünsel Yaklaşım

* Dr. Öğrensici, Ortadoğu Enstitüsü, haydaroruc@hotmail.com 


\title{
From Secularism to Radicalization: Constructivist Transformation in the Founding Philosophy of Israel
}

\author{
Haydar Oruç*
}

\begin{abstract}
Absctract
In this article, it is explored how the transformation in the founder philosophy of the State of Israel, from an identity comprising "secularism", "socialist Zionist values", "pluralism and multiculturalism", "peace", "democratic republic", to a state that is "Jewish ", "keen on religious Zionist values", "conservative" "homogenized culturally and nationally", "a regional power", "a nuclear power", "secure", "belligerent", "a nonconciliatory". Through the concept of constructivism and the principle of reconstruction of the structure and the actor in the context which was acknowledged by Nicholas Onuf and developed by Alexander Wendt into present form, this study endeavours indicating the metamorphosis of the state of Israel and the society. Since the inception to present-day in terms of "norm", "culture" and "identity" with the holistic social constructivist approach.
\end{abstract}

Keywords: Socialist Zionism, Founder Philosophy, Constructivism, Structure-Actor Relation, Holistic Approach

* PhD Student, Middle East Instıtute, haydaroruc@hotmail.com 


\section{Giriş}

İsrail Devletinin kurucu felsefesi olan Siyonizm, esin kaynağı olan Avrupa'daki dönemin yaygın düşüncesi olması hasebiyle sosyalizmin etkisi altında kalmıştır. Devletin kurucu aktörlerinin pek çoğu temelde genel Yahudilik eğitimi almış olan kişiler olsa da dönemin şartları gereği fundamentalist eğilimlerden uzak durulmuştur. Bu aktörler, Siyonist hareketin başlangıcı sayılan 1897 I. Siyonist Kongresinden İsrail devletinin kurulduğu tarih olan 1948 yılına kadar geçen sürede içinde, 1917 Balfour Deklarasyonu ile Filistin topraklarında bir İsrail devletinin kurulmasını destekleyeceğini açılayan İngiltere'nin de yönetici elitlerine hakim olan sosyalist görüşe paralel tutum takınmışlardır.

Devletin kurulmasından 1977 yılında Likud Partisinin ilk kez iktidara geldiği tarihe kadar geçen süre içerisinde sol eğilimli İşçi Partisinin uygulamış olduğu politikalar kabul görmüş ve halk tarafından da desteklenmiştir. 1967 yılındaki savaştan sonra Gazze Şeridi, Batı Şeria ve Doğu Kudüs'ün işgal edilmesiyle Filistinlilere yönelik daha sert politikalar uygulanmaya başlansa da genel bir tercih değişikliğinden bahsetmek için henüz erkendir. Özellikle, 1979 Camp David Anlaşması, 1993 Oslo Görüşmeleri ve 1994 Ürdün Barış Anlaşması bu iklimin doğal sonuçlarıdır. Ancak, 1995 yılında dönemin İşçi Partili başbakanı Rabin'in aşırı dinci bir Yahudi tarafından öldürülmesi İsrail siyasetindeki değişimin başlangıcı sayılır. 1996 genel seçimlerinde Likud'un iktidara gelerek daha radikal politikalar izlemesi bu dönüşümü iyice pekiştirmiştir.

$\mathrm{Bu}$ tarihten sonra İsrail siyasetince tedricen sağa kayma başlamış ve gelinen noktada sol tandanslı partilerin ülke siyasetindeki ağırlığı azalmıştır. Aksine, kendisini merkezde tanımlayan Likud Partisinin başını çektiği koalisyonlarda aşırı dinci partiler koalisyon ortağı olarak değişmez aktörler olarak ortaya çıkmıştır. Aslında, İsrail siyasetindeki bu partilerin tek başlarına veya ittifaklarla iktidar olmaları mümkün değil iken bugün koalisyonlarda ülkenin eğitim, adalet, güvenlik ve dış politikalarına yön veren ortaklar olarak bulunmaları olağanlaşmıştır.

Bu çalışmada, İsrail toplumunun 1980'lerden itibaren başlayan dönüşüm süreci, Sosyal İnşacılık Yaklaşımı temelinde incelenerek, toplumun; iç gelişmeler ve bölgesel/ konjonktürel değişimlerden hareketle başta kimlik olmak üzere din, kültür, güvenlik gibi temel unsurları ön planda tutarak yeniden inşası konu yapılmaktadır. İlk bölümde, sosyal inşacılık yaklaş1- 
mının temel varsayımlardan kısaca bahsedilerek teorik perspektif çizilecek olup ikinci bölümde, devletin kurucu felsefesi olan sosyalist görüşün oluşma şartları ve kendisini nasıl tarif ettiği tartışılacaktır. Üçüncü bölümde, yaşanan dönüşüm; önce iç gelişmeleri içermesi nedeniyle birim düzeyinde, ardından bölgesel ve konjonktürel gelişmeleri içermesi nedeniyle de bütünsel sosyal inşacı yaklaşım ile anlatılmaya çalışılacaktır. Son bölümde ise, İsrail'in mevcut toplumsal yapısı ve toplumun kendini yeniden ifade etme şekilleri üzerinden gelinen nokta sistemik sosyal inşacı yaklaşım ile ifade edilecektir.

\section{Değişimin Teorik Çerçevesi: Sosyal İnşacılık Yaklaşımı}

1980'li yılların sonlarından itibaren uluslararası ilişkiler literatürüne girmeye başlayan inşacılık, uluslararası ilişkileri anlama konusunda yeni bir çerçeve önermeye başlamış ve günümüze kadar gelen tartışmaların seyrinde bir hayli etkili olmuştur. Ancak, tek bir inşacılık türünden bahsetmek mümkün değildir. Disiplinin metinleri incelendiğinde, birçok inşacı yaklaşımın ortaya çıktığı söylenebilir. Uluslararası ilişkiler disiplininde, Alexander Wendt tarafından geliştirilen sosyal inşacılık (social constructivism) kavramının literatüre girmesi ve mevcut kuramsal açıklamalara bir alternatif olması, 1990'lı yıllarla birlikte başlamıştır. Ancak, sosyal inşacılık yaklaş1mının kuramsal altyapısının oluşması, Wendt'ten önceki dönemlerde oluşturulmaya başlanmış ve son olarak Nicholas Onuf tarafindan uluslararası ilişkiler disiplinine uyarlanmıştır. ${ }^{1} \mathrm{Bu}$ bağlamda, sosyal inşacılık yaklaşımı için bir süreklilik ve değişim içinde devam eden inşacı kuramsal yaklaşımların uluslararası ilişkiler disiplininde ortaya çıkan son hâli denilebilir.

Uluslararası ilişkilerde ilk kez "inşacılık" kavramını kullanan Nicholas Onuf, inşacı düşüncenin esin kaynağı olarak Anthony Giddens'ın “yapılandirma kuramını"'2 (structuration theory) kabul etmektedir. Bu kavram pozitivist sosyal bilimler ile modernite eleştirileri arasında bir "orta yol" bulma arayışının sonucu olarak ortaya çıkmıştır. ${ }^{3}$ Kendisini üçüncü yol

1 Nicholas Onuf, World of Our Making: Rules and Rule in Social Theory and International Relations, Columbia: University of South Carolina Press, 1989, Davut Ateş, "Uluslararası İlişkilerde Konstrüktivizm: Ortayol Yaklaşımının Epistemolojik Çerçevesi”, Sosyal Bilimler Dergisi, Cilt:X, Say1:1, Haziran 2008, s. 215

2 Anthony Giddens, The Constitution of Society:Outline of the Theory of Structuration, Berkeley: University of California Press, 1984, s. 162

3 Richard Pierce ve Christian Reus-Smit, "Critical International Theory and 
olarak tanımlayan inşacılık, ontolojiyi öne çıkararak tartışmaya dâhil olmuştur. Kaynağını "yapılandırma" kuramından alarak uluslararası ilişkilere yönelik bir açıklama yapmış, aktör ile yapı arasında hangisinin diğerini ürettiği veya belirlediği konusunda bir tercih yapmanın zorunlu olmad1ğını vurgulamıştır. ${ }^{4}$ Çünkü, Onuf'a göre uluslararası ilişkiler dâhil her tür sosyal ilişki her zaman için aktörlerin ve bu aktörlerin içinde yaşadıkları dünyanın (yapının) birbirini karşılıklı olarak inşa ettiği bir süreçtir. ${ }^{5} \mathrm{Bu}$ nedenle, inşacilığ 1 genel olarak sosyal bilimlerde 1980'li y1llardan itibaren ağırlık kazanan "yapılandırmacılığın" uluslararası ilişkilerdeki izdüşümü olarak değerlendirmek yanlış olmayacaktır. İnşacı düşünce geleneğinin en can alıcı vurgusu olarak görülen devletlerin sosyal bir varlık, uluslararası ilişkilerin de sosyal bir alan olduğu vurgusu, sürekli olarak uluslararası kuralların, normların, kurumların, düşünsel unsurların ve bilişsel faktörlerin rolüne dikkat çekmiştir. ${ }^{6}$

Uluslararası ilişkiler disiplininde inşacılık yaklaşımının "Sosyal İnşacılık" şeklinde literatüre girmesi ise, Alexander Wendt' in çalışmaları ile birlikte olmuştur. ${ }^{7}$ Wendt'in yaklaşımının bu haliyle uluslararası ilişkilere yönelik alternatif bir kuramsal açıklama sunmasını da, Onuf'un inşacılığının geçirdiği epistemolojik dönüşüm ile açılamak mümkündür. Onuf'un bu alandaki eserlerinden yola çıkarak onun inşacılığında üç temel kabulün bulunduğu söylenebilir. Bunlardan ilki, "toplum ve bireyin sürekli biçimde birbirlerini oluşturduğudur" ki burada anlatılmak istenen, birey ya da toplumun verili kavramlar olmadığı, bunun yerine karşılıklı etkileşimlerle bir yapıya kavuştuklarıdır. İkincisi, "dil ve onun türevlerinin (kurallar, kurumlar, politikalar vs.) toplumsal inşa sürecinde birer araç olduğudur”. Çünkü insanlar isteklerini dille ifade edip amaca dönüştürür ve amaçları doğrultusundaki hareketlerini de dille destekler. Üçüncüsü ise, "maddi varlıkların ancak ku-

Constructivism", European Journal of International Relations", Cilt:4, Sayı:3, 1998

4 Onuf, 1989, s. 36-43

5 Ibid, s. 40

6 Mustafa Küçük, "Uluslararası İlişkilerde 'Konstrüktivist Dönüşü’ Anlamak”, Ege Akademik Bakış, Cilt:9, Sayı:2, 2009, s. 776

7 Wendt'in çalışmalarından başlıcaları; "Anarchy is What States Make of It: The Social Construction of Power Politics (1992)", "Bridging the Theory/Meta-theory Gap in International Relations (1991)", "Collective Identity Dormation and The International State (1994), "Constructing International Politics (1995)", "Social Theory of International Relations (1999)", "Driving with the Rearview Mirror: On the Rational Science of Institutional Design (2001)", "The State as Person in International Theory (2004)" dir. 
rallar sayesinde bir kaynak haline dönüştügüüür". ${ }^{8}$

Soğuk Savaş'ın sona ermesi ile birlikte inşacı kuramcılarca epistemoloji tartışması terk edilmeye başlamış, "aktör ve yapı ortak inşası" gibi kavramlar sadece soyut düzeyde bırakılarak inşacı yaklaşımların hızla çeşitlenmeye başladığı bir dönem yaşanmıştır. Bu süreçte, Wendt'in çalışmaları inşacılıkta baskın konuma gelmeye başlamış ve inşacılığın disiplinin anayol kuramlarıyla iç içe geçtiği bir süreç olarak algılanmıştır. Bu sürecin yaşanmasında etkili olan önemli gelişmeler olarak özellikle 1990 sonrası dönemde uluslararası ilişkilerde patlak veren etnik çatışmalar, kimlik ve kültür gibi konuları öncelikli hale getirmiş; ayrıca gücü azalan Marksist kuramcıların gözünde de inşacılığın uluslararası ilişkilerin anlaşılmasında daha cazip hâle gelmesi ile de inşacı yaklaşım hızla yaygınlaşmaya başlamıştır. Buna paralel olarak epistemolojide de keskin bir kayma yaşanmıştır. ${ }^{9}$ Uluslararası ilişkilerin sosyal inşa sonucu meydana geldiğini ve bunun ampirik yöntemlerle belirlenebileceğini, bununla birlikte sosyal inşa süreci devam ettiğinden bugün var olan uluslararası ilişkilerin her zaman değişime açı olduğunu göstermeye çalışmıştır. Böylece Wendt, pozitivist epistemolojinin sosyal ontoloji ile birlikte kullanılarak uluslararası gerçekliğin daha iyi anlaşılabileceğini öne sürmüştür. ${ }^{10} \mathrm{Bu}$ bağlamda, ampirik tartışmalara konu edilen temel başlıklar; konjektürel gelişmelere de bağlı olarak "düşünceler, kurallar, normlar, kurumlar ve kimlikler” şeklinde ortaya çıkmıştır.

Wendt, "uluslararası ilişkilere dair güvenilir bilgi elde etmek için ampirik kanıtlama kullanılmalıdır. Neticesinde devletlerin ve onların oluşturduğu yapıların birer nesnel gerçeklik olmaları ve özne-nesne ayrılığına dayalı olguların bilimsel yöntemlerle incelenmesi gerektiği açıktır"11 açıklamasını yaparken, yaklaşımını iki temel kabul üzerine kurmaktadır. Birincisi, beşeri yapıların maddi güçlerden ziyade ortak düşüncelerle belirlendiğidir. İkinci olarak da aktörlerin kimliklerinin ve çıkarlarının doğa tarafından verilmemiş olduğu, ortak düşünce sırasında inşa edildiğidir. ${ }^{12} \mathrm{Bu}$ inşa sürecinin

\footnotetext{
Onuf, 1989, s. 82-83
}

9 Nicholas Onuf, "World of Our Making: The Strange Career of Constructivism in International Relations", Donald J. Puchala (Der.), Visions of International Relations, Columbia: University of South Carolina Press, 2002, s. 130

10 Wendt, Social Theory of International Relations, Cambridge University Press, 1999, s. 38-39

11 Ibid, s. 90

12 Ibid, s. 77, 110 
gerçekleşmesi için ise en önemli yöntem tanımadır çünkü diğer aktörler tarafindan kabul edilmeyen bir kimlik tek başına anlam ifade etmemektedir. Böylece inşacıllğın en önemli kavramlarından olan "kimliğin" sosyal bir ifade olduğu da söylenebilir. ${ }^{13}$

Wendt tarafından kurgulanmaya çalışılan inşacılığın pozitivist epistemolojiyle ilgisi daha çok yöntem üzerinden kurulmaktadır. ${ }^{14}$ Böylece, inşacı girişimlerin ilk dönemine hakim olan dil, iletişim, kural, norm gibi konular ağırlığını kaybetmeye başlamış; ampirik yöntemlerin uygulanabileceği dış politika, uluslararası örgütler, ittifaklar, kimlikler, çıkarlar ve etnisite gibi konular belli başlı çalışma alanları olarak öne çıkmıştır.

\section{Sosyal İnşacılıkta Aktör-Yapı Etkileşimi}

İnşacı görüşe göre aktörlerin eylemleri norm, kültür, kimlik ve diğer değer esaslı faktörler tarafindan yönlendirilmektedir. $\mathrm{Bu}$ nedenle inşacı yaklaş1ma göre aktörler, kararlarını öznel faktörler, tarihsel-kültürel tecrübeler ve kurumsal bağl1lık temeline dayanan norm ve kurallar ile kimlikleri bağlamında almaktadırlar. ${ }^{15}$ Analiz düzeyi olarak, özneler arası analiz düzeyine vurgu yapan sosyal inşacılık yaklaşımı, norm, kültür ve kimlik gibi sosyolojik kavramları da bu analiz düzeyinde birimler olarak kullanmaktadır. $\mathrm{Bu}$ birimleri açıklamak gerekirse;

Norm, belirli kimlik taşıyan bir aktörden kolektif şekilde beklenen davranıŞ1 tanımlayan kavramdır. Normların ilgili aktörün kimliğini tanımladığı ve/ veya oluşturduğu, onun davranışlarını düzenlediği veya herhangi bir davranışı ona emrettiği veya yasakladığı kabul edilmektedir. ${ }^{16}$

13 Nuri Yurdusev, “Avrupa Kimliğinin Oluşumu ve Türk Kimliği”, Atilla Eralp (Der.), Türkiye ve Avrupa: Batılılaşma, Kalkınma, Demokrasi, Ankara: İmge Kitabevi, 1997, s. 18.

14 Ateş, "Uluslararası İliş̧ilerde Konstrüktivizm: Ortayol Yaklaşımının Epistemolojik Çerçevesi”, Sosyal Bilimler Dergisi, Cilt:X, Sayı:1, Haziran 2008,s. 228-229

15 Henning Boekle,Volker Rittberger ve Wolfgang Wagner, "Norms and Foreign Policy: Constructivist Foreign Policy Theory", German Foreign Policy Since Unification Theories and Case Studies, Volker Ritteberger (ed.), Manchester University Press, 2001, s. $105-140$

16 Ronald L. Jepperson, Alexander Wendt ve Peter J. Katzenstein, "Norms, Identity, and Culture in National Security", Katzenstein J. Peter (ed.), The Culture of National Security: Norms, and Identity in World Politics, Columbia University Pres, New York, 1996, s. 42-45 
Kültür, bir ulus devlet otoritesinin veya kimliğinin gelenek ve hukukla düzenlenmiş kolektif model belirteci olarak ele alınmaktadır. İlgili aktöre değerlendirme ve algılama standartları sağladığı ileri sürülmektedir. ${ }^{17}$

Kimlik ise dar anlamıyla, bir devletin veya ulusun tarihsel ve bir siyasal süreç içerisinde oluşan inşa etiketi olarak ele alınmaktadır. Bireyselcilik ve farkl1lığın imgelerine işaret ettiği belirtilmektedir. Buna göre kimlik, "ötekilerle" ilişkiler sonucunda tasarlanmakta ve biçimlendirilmekte, zamanla yeniden tanımlanmaktadır. ${ }^{18}$ İnşacı yaklaşıma göre, kimlik bir devletin dış politikasında en önemli unsur olarak ortaya çıkmaktadır. İç ve dış siyasetin etkileri sonucu özneler arası bir düzeyde oluşan devlet kimliği, o devletin çıkarlarını tanımlamaktadır ve bu çıkarlar devletlerin dış politika eğilimlerinin belirlenmesini de sağlamaktadır.

Devletlerin kimlikleri öncelikle ulusal düzeyde mevcut sosyo-kültürel değer yargılarına ve siyasal rejim kriterlerine göre oluşmakta ve daha sonra uluslararası düzeyde dış politika perspektifinden girdiği karşılıklı etkileşimlerle kimliğine yeni belirleyici unsurlar katmaktadır. Böylelikle, her iki düzeye ilişkin unsurlar karşı1lıklı olarak birbirlerini destekleyerek dış politikada devlet çıkarlarının biçimlendirilmesinde belirleyici rol oynamaktadır. Ana akım kurumlarından farklı olarak dış politikaya bakış açısında kimliğe ve kimliğin inşa sürecine vurgu yapan sosyal inşacılık yaklaşımı, norm ve kültür kavramlarıyla birlikte sosyal kavramların belirleyici etkisini ortaya koymaktadır. Wendt, uluslararası ilişkilerin sosyal doğası açısından oldukça önemli olan, ama disiplinin hâkim teorilerince büyük oranda göz ardı edilen kimlik, kültür, söylem gibi bir çok faktörün uluslararası ilişkilerde analize dâhil edilmesi ile insan bilinci ve onun uluslararası hayattaki rolünün vurgulanmasının uluslararası ilişkilere konu edilen başlıkların daha iyi anlaşılabilmesi sayesinde mümkün olduğunu iddia etmiştir. ${ }^{19}$

İnşacı anlayışta yapı, hakim teorilerin aksine sabit ve değişmez bir şey olarak görülmemekte; değişim, şarta bağlı olarak mümkün olmaktadır. Wendt, yapının yalnızca maddi kapasitelerden oluştuğu iddiasını da eleştirerek, sosyal ilişkileri de yapının bir parçası olarak sunmaktadır. Ona göre yapı, ortak bilgiler/anlayışlar/beklentiler, maddi kaynaklar ve uygulamalardan

\footnotetext{
Ibid, s. 42-45

Ibid

John Ruggie, Constructing the World Polity: Essays on International Institutionalization, London, Routledge 1998, s. 878, 883
} 
oluşmaktadır. ${ }^{20}$ İnşacılara göre yapının tanımlanmasında ortak bilgiler, anlayışlar, beklentiler önemli bir unsurdur. ${ }^{21}$ Bunlar aktörlerin birbirleriyle olan ilişkilerinin doğasının (işbirlikçi veya çatışmacı) inşasında etkili faktörlerdir. Yapıyı oluşturan bir diğer unsur olarak inşacılar maddi kaynakları göstermektedirler. Fakat burada kavram maddi kaynağın ötesinde, sosyal inşa sonucu anlamlandırılmıştır. İnşacılıkta maddi kaynak tek başına bir şey ifade etmemekte, aktörlerin ona yüklediği anlam ile bir araç olarak kullanılmaktadır. Yapıyı oluşturan son unsur olarak uygulamalar ise, inşacılara göre oldukça önemlidir. Wendt'e göre, "sosyal yapılar ne aktörlerin kafalarında ne de maddi kaynaklarda oluşur. Sosyal yapılar ancak uygulamalarla vardır ve bir sürecin sonucu olarak ortaya çıkarlar."22

İnşacılık disiplinin, kimlik kavramı ile birlikte çıkar kavramını ele alış biçimiyle hâkim teorilerinden keskin bir şekilde ayrıldığı söylenebilir. Çünkü, inşacılığın sosyalliğe yaptığı vurgunun kimlik ve çıkar ilişkisi için de geçerli olduğu mutlaktır. Bir başka deyişle, ana akım kuramlarına göre devletler ve çıkarları teorilerin dışında oluşmuştur. ${ }^{23}$ Wendt, bu teorilerin aktörlerin kimlik ve çıkarlarını dışsal olarak verili kabul etmelerinin ve yalnızca aktör davranışlarının üzerine duruyor olmalarının hatalı olduğu görüşündedir. Çünkü, bu anlayışa göre davranışlar değişebilir, ancak kimlik ve çıkarlar değişmez. ${ }^{24}$ Oysa yine Wendt'e göre, uluslararası politikanın sosyal oluşumunu analiz etmek, aktörlerin kimliklerini ve çıkarlarını ve onların materyal ilişkilerini şekillendiren sosyal yapıları da analiz etmeyi gerektirir. ${ }^{25}$ Yani çıkarların kimliklere dayalı olduğunu söylemek mümkündür.

Sosyal ve normatif unsurların maddi yapılar üzerindeki belirleyiciliğini temel argüman olarak savunan sosyal inşacı yaklaşıma göre, güvenlik kavramı da bu temel üzerine inşa edilmiştir. Ana akım teorilerinin aksine güvenlik konusunun her zaman için olumsuz durumlara ve ikilemlere yol açmadığı savunulmaktadır. Ayrıca devlet merkezli güvenlik okumasının

20 Wendt, "Constructing International Politics", International Security, 20: 1,Summer 1995 , s. 73

21 Ibid

22 Ibid, s. 74

23 Ruggie, s. 862-863

24 Wendt, Anarchy is what States Make of it: The Social Construction of Power Politics, International Organization, Vol. 46, No. 2. Spring, 1992, s. 391-425

25 Wendt, 1995, s. 81 
reddi ve bunun yerine güvenliğin sektörlere ${ }^{26}$ ayrılarak devletin güvenliğin tek sağlayıcısı olmadığı da vurgulanmaktadır. İnşacılığın getirdiği bu alternatif güvenlik okumasında şüphesiz ki Soğuk Savaş sonrası dönemde ortaya çıkan yeni güvenlik tehditlerinin ve Soğuk Savaş döneminde güvenliğin sadece askeri ve teknolojik alanlara indirgenmesinin önemli etkisi vardır.

Buraya kadar anlatılanlardan anlaşıldığı kadarıyla görülmektedir ki, inşacılık yaklaşımının en genel önermesi olan özneler arası sosyal inşa süreci, kimlik ve söylem oluşumu konusunda en önemli faktör olarak ortaya çıkmaktadır. Bu bağlamda, klasik teorik yaklaşımlarının aksine, hem aktörlere hem de yapıya önemli bir rol verilerek, belirleyicilik atfedilmektedir. $\mathrm{Bu}$ yaklaşım; kültür, kimlik, söylem, güvenlik gibi faktörlerin değişebilmesi sayesinde, yapıda da değişime imkan vermesi bakımından, önemli bir avantaj sunmaktadır. Bir sonraki bölümde, İsrail'deki radikalleşme kimlik ve söylem değişimi bağlamında ve inşacılık yaklaşımı perspektifinde ampirik olarak izah edilecektir.

\section{4. İsrail Devletinin Kurucu Felsefesi}

Aktörlerin kimliklerinin, davranışlar üzerinde belirleyiciliği inşacılık yaklaşımının temel varsayımıdır. Dolayısıyla, İsrail'i kuran Siyonist kadrolar incelendiğinde ortaya çıkacak olan tablo da İsrail'in kuruluş felsefenin ip uçlarını verecektir. Bir Yahudi devleti kurulması fikrini ortaya atan ve bunu destekleyen kişi ve kurumların pek çoğu 19. Yüzyıl sonlarından Holokost'un gerçekleştiği döneme kadar Orta ve Doğu Avrupa'da konuşlanmış durumdayd $1 .{ }^{27}$ Holokostun akabinde Filistin'e göçen bu kadrolar, İsrail Devletinin kurulmasında etkili olmuştur. Bu nedenle, Avrupa'nın gelişim, modernlik, eşitlik, özgürlük ve çok kültürlülük gibi geleneksel ideolojik özelliklerinin yanı sıra toplumsal yapıda devletin rolüne yönelik tartışmalar da kurucu elit ile birlikte İsrail devletinin kurulması aşamasında kurucu felsefe olarak etkili olmuştur. ${ }^{28}$ Hatta, bu ifadeyi daha ileri götürerek, "İsrail sosyalist devrimciler tarafından kurulmuştur" şeklinde aktaranlar bu-

26 Barry Buzan, Ole Wæver, Jaap de Wilde, Securitiy: A New Framework for Analysis, London: Lynne Rienner Publishers, 1998, s. 7-8.

27 Derek J. Penslar, Israel in History The Jewish State in Comparative Perspective, Routledge, NY, 2007, s:135

28 Eliezer Ben-Rafael, Yochanan Peres, Is Israel One? Religion, Nationalism and Multiculturralism Confounded, Brill, Lieden, 2005, s:246 
lunmaktadır. ${ }^{29}$ Yahudi kimliği ve dindarlığ İsrail'i oluşturan Yahudi toplumunun her zaman önceliği olmuştur. Devletin dinsel konulardaki yaklaşımı ve dini kurumarın ne ölçüde kurucu faktör olarak kabul edilmesi gerektiği hakkında tartışmalar kuruluş öncesinde başlamış ve devletin ilanına kadar devam etmiştir. Ancak, din ile devlet ve Yahudilik ile Siyonizm arasında yaşanması muhtemel tartışmalar döneminin hassas küresel konjonktüründe devletin kurulmasına veya hayatta kalmasına imkan sağlamayacağı gerekçesiyle hasır altı edilmiştir. ${ }^{30} \mathrm{Bu}$ sebepten dolayıdır ki, 14 Mayıs 1948 tarihinde David Ben-Gurion tarafından okunan devletin kuruluş bildirgesinde; İsrail Devletinin, “din, dil, vicdan, eğitim, cinsiyet ve kültür özgürlüğünü teminat altına aldığ 1 , tüm etnik kimliklere sayg1 gösterileceği, her vatandaşa eşit ve tarafsız davranılacağ 1 ve hakkaniyet gösterileceği, tüm dinlerin kutsallarına saygı gösterileceği ve korunacağı" vaat edilmiştir. ${ }^{31}$ Bu sayede, zımnen de olsa bölgedeki genel politik iklimden farklı bir biçimde ve dönemine göre çok yenilikçi bir sosyal mutabakat ile Batılı değerlere sıkı sıkıya bağlı hatta onun da ilerisinde bir devlet oluşturulmuştur. Gerçi, sosyal mutabakatın bir anayasaya dönüştürülememesi dini kesimler ile Siyonist elit arasındaki anlaşmazlığa bağlansa da bu durum kuruluş evresinde önemli bir sorun teşkil etmemiştir.

\section{Radikalleşmenin Sosyal İnşacı Yaklaşımla Açıklanması}

İsrail'de 1970'lerin sonlarından itibaren başlayan değişimin yukarıda anlatılan kuramsal çerçeve bağlamında analizi yapılırken iki teorik önerme ön plana çıkmaktadır. İlki, yapı ve aktör arasında belirleyicilik noktasında bir ayrım yapmaksızın bu iki kavramın eşit kabul edilmesi, ikincisi ise, ilişkilerin anlamlandırılması bağlamında, özneler arası analiz düzeyinin hem aktörün varlığı hem de yapının oluşması noktasındaki belirleyiciliğidir. $\mathrm{Bu}$ çalışmada, aktör olarak; İsrail'in iç ve dış politikasının oluşumunda etkin olan dini hareketler, siyasi partiler, diaspora, göç hareketleri, Filistin halk1 ve yönetimi, Hamas, Hizbullah ve İslam-1 Cihad gibi radikal örgütler, İran, $A B D$ ve $A B$ gibi küresel oyuncular ile diğer bölge ülkeleri, yapı olarak ise, aktörlerin etkileşimi sonucu oluşan genel siyasa kabul edilmektedir.

29 Jerold S. Averbach, Jewish State Pariah Nation Israel and the Dilemmas of Legitimacy, Quid Pre Books,New Orleans,2014, s:40 (e book)

30 Derek J. Penslar,a.g.e., s:34

31 Victor Kattan, From Coexistence To Conquest, International Law and the Origin of the Arab-Israeli Conflict 1891-1949, PlutoPress,2009, s.232 
İsrail kuruluş evresinde kendisini; "seküler", "sosyalist Siyonizm değerlerine bağlı", "çoğulcu ve çok kültürlü”, "barışc1l”, "demokratik bir cumhuriyet" kimliği ile tanımlarken zamanla iç ve dış gelişmelerin de etkisiyle; "Yahudi Devleti", "dindar Siyonizm değerlerine bağlı", "muhafazakar", "tek millet ve tek kültür", "bölgesel güç”, "nükleer güç", "güvenlikçi”, "savaşçı", "tavizsiz", "etrafı düşmanlarla çevrili bir vaha" olarak tanımlamaya başlamıştır. Böylelikle devlet ve toplum kuruluş akdinin tam tersi mahiyette söylemlerle radikalliğe evrilerek yeni bir "kimlik" inşa edilmiştir. Yaşanan radikalleşmenin iç gelişmelerden kaynaklanması nedeniyle birim düzeyinde (unit level) ${ }^{32}$ aynı zamanda bölgesel ve küresel gelişmelerin de etkisi nedeniyle sistemik yaklaşımla ${ }^{33}$ ele alınması gerekmektedir. Dolayısıyla, yapılacak analizde her iki yaklaşımı barındırması sebebiyle, bütünsel (holistic) $)^{34}$ sosyal inşacı yaklaşım tercih edilecektir. Dönüşüm sürecini etkilediği varsayılan olaylar ampirik verilerle, iç-dış gelişme ayrımı yapılmadan sunulacaktır.

\section{Arap-İsrail Savaşları (1948, 1967, 1973)}

Nazi Almanya'sında maruz kalınan soy kırımdan (Holokost) sonra gelip yerleştikleri Filistin topraklarında kurulan İsrail Devleti de Yahudilerin huzura ermesini sağlayamamıştır. Zira, BM'nin 1947 tarihli ve 181 (II) A sayılı "Taksim Planı" sayesinde üzerine kondukları topraklarda yaşayan yerli bir halk (Filistinli Araplar) zaten mevcuttu ve kimse bu yerli halka topraklarını paylaşmak isteyip istemediklerini sormamıştı. Bu yüzden, 14 Mayıs 1948 tarihinde İsrail Devleti ilan edilir edilmez aralarında Misır, Suriye, Lübnan, Ürdün ve Irak'ın bulunduğu Arap orduları Filistin topraklarına girerek yeni kurulan İsrail Devletine savaş açmışlardır. ${ }^{35}$ Ancak, aralarında yeterli işbirliği ve koordinasyon bulunmayan Arap orduları karşısında İsrail'in henüz teşkilatını tamamlamamış Hagana ve Irgun gibi milis güçlerin desteği sayesinde ayakta duran ordusu galip gelmiştir. Taksim planı sayesinde Filistin toprağının \%56'sına sahip olan İsrail, savaşın akabinde bu

32 Christian Reus-Smith, Constructism, Scott Burchill (ed.), Theories of International Relations, Palgrave Macmillan, Basingstoke,2009, s.220

33 Ibid,s:223

34 Ibid,s:225

35 Burcu Güçlü Akpınar, “Arap-İsrail Savaşlarının Etkileri”, Ortadoğu Analizi İki Kutuplu Sistem Sonrası Ortadoğu ve Arap Baharı, Hasret Çomak, Caner Sancaktar (ed.),Beta,İstanbul,2014,s.327 
oranı \% 77 'ye genişletmiştir. ${ }^{36}$

$\mathrm{Bu}$ genişlemenin sonrasında, İsrail parlamentosu tarafından bu bölgelerde yaşayan yerli halkın tahliye edilmesine karar verilmesi üzerine Filistinli mülteciler problemi olarak bilinen kadim sorun başlamıştır. Yerlerinden edilen yaklaşı 700.000 ile 900.000 arasındaki Filistinli başta Ürdün olmak üzere Lübnan, Suriye ve Filistin topraklarının diğer bölgelerine göç etmek zorunda kalmıştır. ${ }^{37}$ Filistinlilerin boşaltmak zorunda kaldığ 1 yerlere yaklaşı 500.000 Yahudi yerleşimci yerleştirilerek, bu bölgelerde nüfus üstünlüğü değiştirilmiştir. ${ }^{38}$ Yaygın nüfus hareketleri, İsrail toplumunda "vaat edilmiş topraklara" kavuşmak yönünde olumlu bir etki yapsa da, Arap ülkelerinde de İsrail tehdidine karşı Arap milliyetçiliğini körüklemiştir.

1967 yılına gelindiğinde ise, Arap ülkelerinde yaşanan devrimler sonucunda monarşik rejimler yıkılmış, yerine kurulan cumhuriyetlerin yaratmış olduğu değişim dinamiği bölgede hüküm süren diğer monarşileri rahatsız hale gelmiştir. Bu şartlar altında aralarında bir dayanışma olmadığı gibi gizliden bir rekabet de söz konusuydu. Özellikle, Nasır liderliğindeki Mısır'ın öncülük ettiği Arap ülkeleriyle İsrail arasında yer yer sınır çatışmaları yaşansa da resmen bir savaş hali söz konusu değildi. Ancak, Rus'ların da yanlış yönlendirmeleriyle İsrail'in Suriye sınırına asker yığmasını kendisine yönelik bir tehlike olarak gören Nasır, Mayıs 1967'de BM'den Misır-İsrail sınırında bulunan Barış Gücünü çekmesini istemiş ve ardından Tiran Boğazı'nı kapatarak İsrail'in Kızıldeniz'e çıkışını engellemiştir. 1956 Süveyş Krizinden beri bu hattı kullanamayan İsrail için, Tiran Boğazının kapatılmasının savaş sebebi sayılacağı ilan edilmiş ve ardından da 5 Haziran 1967 tarihinde Mısır, Suriye ve Ürdün'e eş zamanlı olarak saldırılmıştır. ${ }^{39}$ Kısa sürede her üç cephede de büyük başarılar elde eden İsrail, savaş sonrası Batı Şeria, Gazze Şeridi, Sina Yarımadası ve Golan Tepelerini topraklarına katmıştır. Özellikle, 1948 sonrası doğu-batı olarak ikiye bölünen ve o tarihten itibaren Ürdün tarafindan kontrol edilen Mescid-i Aksa külliyesinin de bulunduğu Batı Kudüs'ün İsrail'in eline geçmesiyle, günümüze kadar süren ve anlaşmazlığın merkezinde olan Kudüs'ün statüsü sorunu başlamıştır. Tersinden okumak gerekirse de, Yahudiler 2000 yıl önce kutsal

$36 \quad$ Ibid,s.328

37 Tayyar Ar1, Geçmişten Günümüze Ortadoğu Siyaset, Savaş ve Diplomasi, MKM, Bursa,2012 (5. Bask1), s.282-283

38 Burcu G.Akpınar,a.g.e., s.329

39 Burcu G.Akpınar,a.g.e., s.334 ve Tayyar Arı, a.g.e.,s.288-289 
mabetlerinin yıkıldığı bölgeyi tekrar geri almışlardır. Bu durum, o tarihe kadar siyasi bir anlaşmazlık olan Arap-İsrail çatışmasını dini bir çatışma haline getirmiştir.

Tarihe Altı Gün Savaşı olarak da geçen 1967 savaşında Arap ordularının büyük zayiat vererek savaşı kaybetmesi beraberinde Nasır'ın ve Arap milliyetçiliğinin sonu olmuştur. ${ }^{40}$ Arap Halklarının gördüğü kısa süreli de olsa rüya sona ermiş ve bölgenin Arap devletleri İsrail için tehlike olmaktan çıkmıştır. ${ }^{41}$ Ama, bu yenilginin de etkisiyle toplanan Arap Birliği, Eylül 1967 'de, "İsrail'i tanımama, İsrail ile görüşmede bulunmama ve İsrail ile barış yapmama" gibi radikal kararlar almıştır.

BM'nin 1967 Savaşı sonrası almış olduğu 242 sayılı, İsrail'in 1967 öncesi sınırlara çekilmesini öngören kararının İsrail tarafından uygulanmamasını gerekçe göstererek, 1967 savaşında kaybedilen toprakları geri almak isteyen Mısır, 6 Ekim 1973 tarihinde yani Yahudiler için kutsal sayılan Yom Kippur Bayramında Suriye ile eşgüdümlü olarak İsrail'e saldırmıştır. Başlarda ani saldırının da avantajıyla üstünlük sağlayan Arap kuvvetleri, İsrail'in toparlanmasıyla yeniden hezimete uğramıştır. Savaşın ardından Petrol İhraç Eden Ülkeler Örgütü (OPEC)'nün Arap üye devletleri Mısır ve Suriye'ye jest olarak, İsrail'e ve İsrail'e bu savaşta yardım eden Batılı ülkelere karşı petrol ambargosu uygulamaya başlamıştır. ${ }^{42}$ Ambargodan etkilenen Batılı ülkeler, BM'yi de devreye sokarak Araplar ile İsrail arasında süre giden anlaşmazlığın çözümlenmesi için daha fazla gayret göstermeye başlamışlardır. Özellikle ABD'nin sergilediği mekik diplomasisi sayesinde İsrail ile Arap devletleri arasında yapılan anlaşmaların yolu açılmış ve bu şekilde sorun Arap-İsrail sorunu olmaktan çıkarak, İsrail-Filistin meselesi haline gelmiştir. Ancak, bu durum İsrail'e fazla bir avantaj sağlamamıştır. Zira, İsrail'in karşısına artık düzenli ordular değil Filistinli gerillalardan müteşekkil edilen örgütler çıkmaya başlamış ve bu durum ülkeyi daha güvensiz bir hale getirmiştir. ${ }^{43}$

\section{1977 Seçim Sonuçlarının Etkisi}

Filistin topraklarında 1922 yılında başlayan İngiliz Manda yönetimiyle

\footnotetext{
40 Tayyar Ar1, a.g.e.,s.296

$41 \quad$ Ibid,s.297

42 William L. Cleveland, Modern Ortadoğu Tarihi, Agora, İstanbul,2008,s.419

43 Burcu G.Akpınar, a.g.e., s.339
} 
birlikte kurumsal hale gelen Yahudi partileri genelde dört eğilimden meydana gelmekteydi. Bunlar; en önemli grup olan sosyalist eğilimli Siyonist İşçi Partisi, Revizyonistler, milliyetçi Siyonistler ve Mafdal ile Ulusal Dini Partinin başını çektiği küçük dini partilerden oluşan muhafazakarlardır. ${ }^{44}$ Devletin kurucusu olan sosyalist eğilimli İşçi Partisi, 1977'ye kadar koalisyonlarla da olsa ülkeyi tek başına yönetmiştir.

İsrail'in, özellikle 1967 ve 1973 savaşlarından sonra bölgedeki Arap ülkeleri tarafından izole edilmesi ve BM menşeili kararlarla 1967 sınırları öncesine dönülmesi konusunda baskı yapılması doğal olarak iç politikada da bazı değişikliklere sebep olmuştur. Çünkü, kuruluştan itibaren devlet aygıtına kumanda eden iktidar partisi olan İşçi Partisi (Mapai), ülkeyi girilen bu türbülanstan çıkarmakta zorlanmaya başlamıştır. 1977 yılında gerçekleşen seçimler öncesinde, seçmen eğilimlerinin belirlenmesine yönelik olarak yapılan anketlerde, İşçi Partisi ile diğer partilerin söylemleri ve programları arasında fazla bir fark algılanmadığı ortaya çıkmıştır. ${ }^{45}$ Hatta, kampanyanın sürdüğü son dakikaya kadar yine 1973 seçimlerine benzer bir sonucun ç1kacağı beklentisi mevcuttu. Ancak, seçim sonucuna yönelik yapılan tahminlerde, sonucu kararsızların belirleyeceği öngörülmekteydi. Seçim sonucunda Likud'un kazandığı başarı ise kendisi için bile sürpriz olmuştu. ${ }^{46} \mathrm{Bu}$ sonuç, devletin kuruluşundan beri ilk kez yönetimin el değiştirilebileceği anlamına gelmekteydi ki, ardından yapılan "tek parti rejiminin sonu" ve "ikinci cumhuriyetin kurulması" gibi betimlemeler haksız da sayılmazdı. ${ }^{47}$

Likud'un seçim zaferini, İşçi Partisi’nin önderliğindeki ittifakın uygulamalarından rahatsız olan geniş kitlelerin tepkisi olarak açıklayan yorumlar olduğu kadar, Asya ve Afrika kökenli (Mizrahi) Yahudilerin, devletin kurucusu olan Avrupa kökenli (Aşkenaz) Yahudilerin hegemonyasına bir tepki olarak yorumlayanlar da mevcuttur. ${ }^{48}$ Sonuçta, 1977 seçimleri İsrail'in siyasal ve sosyal yapısında köklü bir değişikliğe kapı açan bir eşik görevi görmüştür. O tarihe kadar hesaba katılmayan hatta ikinci sınıf olarak hor görülen doğulu Yahudiler, politik arenaya adım atmıştır. Oylarıyla politika

44 Clive Jones-Emma C.Murphy, Israel Challenges to Identity, Democracy and The State, Routledge, London, 2002, s.35

45 Jonathan Mendilow, Ideology, Party Change and Electrol Campaigns in Israel, 1965-2001, State University on NY,2003,s.82

46 Ibid,s.83

47 Ibid,s: 83

48 Ibid,s:83 
vitrinini değiş̧irebileceklerini fark eden geleneksel dindar seçmenler Likud Partisini bir kitle partisi haline getirmiştir. Bu tarihten sonra Likud, iktidarda olmadığı dönemlerde bile İsrail'in politikalarının belirlenmesinde etkili bir figür haline gelmiştir. 1973 Savaşı sonrası ülkenin içerisinde bulunduğu zor ekonomik koşullarda, savunma harcamalarına ayrılan bütçenin gayri safi milli hasılanın \%40'na tekabül etmesi, zaten zor koşullarda yaşamaya çalışan halkın kendilerine şans verilmesini isteyen ve daha iyi bir gelecek vaat eden muhafazakar partilere kayması toplumsal dönüşümün başlangıcı olarak görülmektedir.

\section{Camp David Anlaşması}

İsrail'in bölgedeki yalnızlığına son vermek ve bölgedeki diğer müttefikler ile işbirliğini mümkün kılmak için ABD öncülügünde başlatılan girişimler sonucunda, İsrail ile Mısır arasında 1979 yılında Camp David Anlaşması imzalanmıştır. Anlaşma öncesinde, Mısır Cumhurbaşkanı Sedat'ın Kudüs ziyaret etmesi ve Knesset'te İsrail parlamenterlerine hitap etmesi anlaşmaya zemin hazırlasa da, İsrail hükümetinin; Sina'dan çekilme, 1967 sınırlarının öncesine dönülmesi, Kudüs'ün statüsünün belirlenmesi ve Filistinli mültecilerin yurtlarına dönmesine imkan sağlanması gibi konularda üzerine düşeni yapmamasıyla barış süreci çıkmaza girmiştir. Ancak, aynı tarihlerde İran'da yaşanan rejim değişikliğini iki ülkenin de tehdit olarak algılaması nedeniyle anlaşma imzalanmış ve anlaşmanın Sina'dan çekilmek ve Yahudi yerleşimcilerin buralardan sökülmesi hükümleri gecikmeli olarak 1982 tarihinde uygulanabilmiştir. ${ }^{49}$

Camp David Anlaşmasıyla İsrail'in çevresindeki Arap izolasyonu bir nebze de olsa kırılabilmişti. Bu sayede güney sınırla güvenlik altına alınmış ve Mısır'ın arabuluculuğu sayesinde Filistinliler ve ardından Ürdün ile barış görüşmelerinin yolu açılmıştır. Ancak, 1967'den itibaren Sina'ya yerleştirilen Yahudi yerleşimcilerin buradan sökülmesi sürecinde dramatik olaylar yaşanmış ve bu olaylar toplumsal bir travmaya yol açmıştır. Hatta, atalarının toprakları olarak gördükleri Sina'dan çekilmenin bir günah olduğunu düşünen ve buna karşı mücadele eden Gush Emunim gibi radikal örgütler toplumda etkili olup, hükümet karşıtı gösteriler tertip etmişlerdir. ${ }^{50}$

\footnotetext{
Tayyar Ar1, a.g.e.,s.334

50 Israel Shahak, Norton Mezvinsky, İsrail'de Yahudi Fundamentalizmi, çev.Ahmet Emin Dağ, Anka,İstanbul,2004,s.136-137
} 


\section{9. İran İslam Devrimi}

İran'da 54 y1l (1925-1979) hüküm süren Pehlevi Hanedanlığı ile resmi olmasa bile 1950'li yıllardan itibaren, dönemin Başbakanı David Ben-Gurion'un “çevre doktrini”" gereğince iyi ilişkiler kurmuş olan İsrail için, 1979 tarihinde gerçekleşen İran İslam Devrimi sonrası İran'ın kaybedilmesi Holokost'tan sonraki en büyük travma olarak algılanmaktadır. ${ }^{51}$ Zira, bölgede Arap olmayan üç ülkeden biri olan ve çok sıkı askeri ve ekonomik işbirlikleri kurulmuş olan İran'ın, artık İsrail'i düşman olarak görmeye başlamas1, bütün münasebetini keserek bölgede İsrail'e karşı Filistinlileri ve diğer radikal örgütleri desteklemesini hazm etmek kolay olmamıştır. Ayrıca, Humeyni'den itibaren yönetime gelen bütün liderlerin İsrail'in varlığına yönelik şiddetli eleştirilerde bulunmaları ve Araplarla İsrail arasında sürdürülen barış görüşmelerini sabote etmeye çalışmaları da yaşanan dönüşümün en bariz örnekleridir. ${ }^{52}$

İsrail'i eleştirmenin diğer Müslümanlar üzerindeki etkisini hisseden İran, elindeki kozu daha etkili hale getirmek adına ilerleyen y1llarda nükleer silah kartını da kullanmıştır. Bunun sonucu olarak İsrail toplumunda, büyük bir kırılma yaşanmıştır. Hem nükleer silah tehdidi nedeniyle Holokost korkusu depreşmiş hem de İran'ın kullandığı yoğun dini argümanlar nedeniyle Müslümanlara karşı bir nefret dili oluşmaya başlamıştır. ${ }^{53}$ İran Devriminin yaratmış olduğu dinamikler nedeniyle, bölgedeki Arap ülkelerinde hakim olan seküler toplumsal yapıların da tedricen muhafazakarlığa kaydığını ve Ortadoğu'yu yeniden Müslüman bir coğrafya haline dönüştürdügünü söylemek mümkündür. ${ }^{54} \mathrm{Bu}$ olaydan sonra, İsrail Devletinin kuruluşundaki çok kültürlülük ve çok dinlilik gibi evrensel değerlerin etkisi azalmış ve bu değerleri destekleyen siyasal partiler taban kaybetmiştir. Yani, İran İslam Devriminin İsrail'de esnemeye başlayan geleneksel değerleri hatırlatıcı etki yaptığını ve toplumu konsolide ederek tekrar birleştirdiği, bunu yaparken de toplumu daha radikalleştirerek dini referansları ağır basan bir yönetime kaydırdığını söylemek mümkündür.

51 David Menashr1,Iran,Israel and the Middle East Conflict, Israel Affairs, 2006,12:1

52 Fatma Aslı Kelkitli," İdealizm ve Realizm Sarkacında Soğuk Savaş Sonrası İran Dış Politikası", Ortadoğu Analizi İki Kutuplu Sistem Sonrası Ortadoğu ve Arap Baharı, (ed.) Hasret Çomak-Caner Sancaktar, Beta, İstanbul, 2014,s.223-225

53 Bernard Hourcade, "Iran Facing Israel", The World Facing Israel-Israel Facing the World, Images and Politics, Alfred Wittstock (ed.), Berlin, 2011,s.117-121

$54 \quad$ William L. Cleveland, a.g.e.,s.485-488 


\section{0. İntifada Hareketleri}

İsrail'in, Batı Şeria ve Gazze'de Filistinlilere yönelik uygulamış olduğu olumsuz politikalar (işgal, işkence, yargısız infaz, mala el koyma, asimile politikaları, sosyal yardımların kesilmesi, yanlı eğitim politikaları, vs.) Filistin halkının milliyetçilik duygularını ve insanca yaşama isteklerini kabartarak, 1987 yılında kendiliğinden bir tepki oluşmasına sebep olmuştur. FKÖ'nün muhatap alınmadığı bir ortamda herhangi bir temsilci bulamayan halk kendi tepkisini uluslararası kamuoyunun gözü önünde sapanla taş atarak vermeye çalışmıştır. ${ }^{55}$ Görüntülerin haber ajanslarında yayınlanmaya başlaması ile bütün dünya, sapanla kendisini savunan çocuklara İsrail askerlerinin nasıl orantısız güç kullanarak cevap verdiğini ilk kez bu kadar net şekilde görmüştür. İsrail'in o tarihe kadar meşru müdafaa olarak dünyaya anlattıklarının aslında gerçek olmadığı görülmüş ve İsrail'e yönelik olarak insan hakları ihlallerinden vazgeçmesi konusunda yoğun baskı yapılmaya başlanmıştır. 2000 yılında da Ariel Şaron'un beraberindeki binlerce kişiyle birlikte Mescid-i Aksa'ya girerek güç gösterisinde bulunmasıyla tetiklenen ikinci intifada hareketinde de benzer görüntüler yaşanmıştır.

Her iki intifada hareketinin getirmiş olduğu sonuçlar itibariyle İsrail toplumunda bir değişiklik yaşanması kaçınılmaz olmuştur. Bu değişikliklerin ilk cephesi doğal olarak ordu olmuştur. Zira 1948'den itibaren yaşanan savaşlar nedeniyle dış tehdide göre kurgulanmış olan İsrail ordusu alışılmadık bir tehlikeyle karşı karşıya kalmıştır. Güvenlik stratejilerinde öngörülmeyen bu kalkışmayı engellemekte güçlük yaşayan ordu, kısa bir bocalamanın ardından tedricen tedbirlerini sıkılaştırarak daha güvenlikçi politikalar uygulamaya başlamıştır. Filistinlilere karşı üstünlük sağlayamayan bir İsrail ordusunun diğer Arap ülkeleri nazarında bir caydırıcıllğ 1 kalmayacağ1n1 öngören güvenlik bürokrasisis ${ }^{56}$, bölgesel bir meydan okumaya muhatap olmamak için ne olursa olsun başkaldırının bastırılmasında mutabık kalmıştır. Buna mukabil uygulanan politikaların bir sonucu olarak İsrail toplumundaki tehdit algılaması da değişerek toplumu daha da radikalleştirecek mahiyete bürünmüştür. ${ }^{57}$

İntifada hareketlerinin bastırılması kapsamında askeri harcamalardaki yük-

Bülent Aras, Filistin-İsrail Barlş Süreci ve Türkiye, Bağlam,İstanbul,1997,s.50-51

56 Efraim Inbar, Israel's National Security, Issues and Challenges Since The Yom Kippur War, Routledge, NY,2008, s:53

57 Ibid,s:42 
sek artışı karşılamak için sosyal yardımlarda yapılan kesintiler toplumda yeni bir asabiyeye daha yol açmıştır. Çatışma ortamı nedeniyle yeni yatırımların durmasına bağlı olarak yaşanan işsizlik ve ekonomik daralma, yeni ve refah içerisinde bir hayat arzusuyla İsrail'e gelen Yahudi göçmenlerde bir aidiyet meselesine yol açmıştır. Güvenlik kaygılarının üzerine eklenen ekonomik sorunlar toplumun bazı kesimlerinde "bu kadar sıkıntıya değer mi?" sorularına yol açmıştır. ${ }^{58}$

Bu değişime ilave olarak, kuruluşundan itibaren Batı'dan zımni de olsa sürekli destek alan İsrail, dünyadaki küresel insan hakları hassasiyetinin de etkisiyle ilk defa yoğun dozda eleştiriler almaya başlamıştır. Batı kaynaklı baskılar nedeniyle köşeye sıkışan İsrail, Filistin Yönetimi ile barışa zorlamıştır. Fakat bu dönemden sonra İsrail devletinin kurucu felsefesini teşkil eden Batılı değerler sorgulanmaya, Batıya olan güven azalmaya başlamıştır. $^{59}$

\section{Oslo Görüşmeleri}

İsrail Devletinin kurulduğu 1948 tarihinden itibaren aynı topraklarda yaşayan diğer asli unsur olan Filistinliler ile yaşanan toprak, sınırlar, mülteciler, yerleşimciler, Kudüs'ün statüsü gibi temel meselelerin çözümüne yönelik olarak 1993 yılında Washington'da imzalanan Prensipler Anlaşmasıla başlar Oslo Barış Süreci. Ancak, bu sürecin ortaya çıkışının temel kaynakları olarak, 1987'deki birinci intifada ve 1991 Madrid Barış Konferansı gösterilebilir. ${ }^{60}$ İntifada ile başlayan süreci etkileyen Sovyetler Birliği'nin çöküşü ile buradan İsrail'e göç eden binlerce Yahudinin sebep olduğu yeni durum ve 1. Körfez Savaşı sonrası ABD'nin fiili olarak bölgeye gelmesi gibi etmenler bu süreci zorunlu kılmıştır. Tarafların birbirlerinin varlığını ve meşruiyetini kabul etmeleri, İsrail askerlerinin ve Yahudi yerleşimcilerin Gazze'den çekilmesi, özerk bir Filistin yönetiminin kurulması gibi maddi kazanımları olan anlaşmalar serisinde İsrail tarafının masadaki gündem maddelerine rağmen, 1967 sınırlarına dönmek, Batı Şeria'daki Yahudi yer-

58 İntifada hareketlerinin ekonomik sonuçları için bakınız; Shlomo Swirski, "The Burden of Occupation, The Cost of the Occupation to Israeli Society, Polity and Economy”, Adva Center, Center of Information on Equality and Social justice in Israel, 2008

59 Gerald Cromer, A war of Words: Political Violence and Public Debate in Israel, Frank Cass, 2004, s:115

60 Bora Bayraktar, Oslo Barış Süreci İsrail-Filistin Barış Görüşmeleri, 1991-2000, Küre, İstanbul, 2013, s.111 
leşimcilerin yerinden edilmesi, Filistinli mültecilerin geri dönmesinin sağlanması ve Kudüs'ün paylaşılması gibi maddelerde istekli davranmaması hatta ayak sürümesi nedeniyle süreç tam olarak işletilememiştir. ${ }^{61}$ Yine de, Oslo Görüşmelerinin 1994 yılında İsrail ile Ürdün arasında yapılacak olan Wadi Barış Anlaşmasının yolunu açması ve muktesebatın kademeli olarak uygulanması sayesinde Gazze'nin işgalinin sona ermesi ve yarı özerk bir Filistin Yönetimine imkan vermesi açısından başarılı bir süreç olarak nitelemek mümkündür.

Oslo Görüşmelerinin başlamasından itibaren, İsrail toplumundan farklı sesler de duyulmaya başlanmıştır. İki toplumun beraber ve barış içerisinde yaşama imkanının ortaya çıkmasına rağmen, "Filistin yönetiminin anlaşmadan daha karlı çıktığı", "vaat edilen toprakların pazarlık konusu yapılamayacağı", "devlet içinde devlet olmayacağı", "Kudüs'ün statüsünün tartışılamayacağı” gibi enstrümanlar ile görüşmelere karşı çıkan köktendinci ve revizyonist gruplar anlaşmanın başarısızlığa uğraması için ellerinden geleni yapmışlardır. Hatta, 1995 yılında gerçekleşen Rabin suikastının faili de bu grupların içinden çıkmıştır. ${ }^{62}$ Dolayısıyla, Oslo Görüşmelerinin iki toplumun geleceği açısından her ne kadar olumlu etki yarattığını söylemek mümkünse de, İsrail toplumundaki ayrışmayı derinleştirdiğini söylemek de mümkündür. Özellikle, yerlerinden edilen Yahudi yerleşimcilerin devlet tarafından ihanete uğradıklarını düşünmeye başlamaları ve devletin çıkarları söz konusu olunca kişisel çıkarların göz ardı edilebileceğini fark etmeleri toplumda yeni ve daha radikal bir katman yaratmıştır.

\section{Rabin Suikastı}

İsrail ile Filistin Yönetimi arasında ABD'nin gözetiminde Oslo'da yürütülen barış görüşmelerinin bir sonucu olarak Gazze'de bulunan Yahudi yerleşimcilerin zorla yerlerinden edilmeleri İsrail toplumunu neredeyse bir iç savaşın eşiğine getirmiştir. ${ }^{63} 1993$ Oslo ve 1994 Ürdün Barış Anlaşmalarının mimarı olan İşçi Partisinin başındaki isim olan Rabin, bu anlaşmalar nedeniyle Gush Emunim ve NRP tarafindan hedef haline getirilmiştir. Hat-

\footnotetext{
Ibid,s.221

62 Ibid, s.233

63 Yochanan Peres, 'Internal Constraints On The Arab-Israeli Peace Process: An Israeli View", Palestine Jordan Israel Building a Bas efor Common Scholarship and Understanding in the New Era of the Middle East, PASSIA, Kudüs,1997,s.30
} 
ta, sivil idarenin kararlarını uygulamak durumunda olan güvenlik güçlerinin, hükümetin anlaşmalardaki tavrı nedeniyle yerleşimcilerin bulundukları yerlerden çıkarılmaları hakkındaki emirleri uygulamayarak fiili durum yaratabileceklerine yönelik duyumlar ortaya atılmıştır. ${ }^{64}$ Hatta, ordu içine sızan NRP üyesi radikal Yahudilerin İsrail'in laik yapısını değiştirerek Tevrat ve Torah'da emredilen şekilde dini bir yaşam sürülmesini sağlayacak girişimlerde bulunabilecekleri iddia edilmiştir. ${ }^{65}$ Likud Partisinin önderliğinde diğer sağc1 ve radikal gruplarla düzenlenen gösterilerde Rabin, Yahudi yerleşimlerinin yerlerinden sökülmesiyle bağlantılı olarak Nazi üniforması giymiş bir "despot" olarak gösterilerek, pek çok din adamı tarafindan "düşmanın iş birlikçisi”" ve "onların kararlarının uygulayıcısı" olarak lanse edilmiştir. ${ }^{66} \mathrm{Bu}$ yoğun kışkırtma ve karalama kampanyasının sonucunda Başbakan Rabin, 4 Kasım 1995 tarihinde dindar bir milliyetçi olan Yigal Amir isimli bir Yahudi tarafından öldürülmüştür. ${ }^{67}$

Rabin suikastının ardından Şimon Peres Başbakan olmuş ve iki hafta içerisinde Arap partilerinin dışarıdan destekliği yeni bir azınlık hükümeti kurmuştur. Yeni kurulan kabinenin yapısı, Rabin hükümetinin hemen hemen aynısıydı. Arada tek bir fark vardı, radikal Meimad hareketinin lideri olan Haham Yehudal Amital'nn bakan olarak hükümette yer alması. ${ }^{68}$ Böylelikle, Rabin'in öldürülmesinden gerekli mesajın alındığı ve dindar kesim ile yerleşimcilerin, önceki döneme göre daha ayrıcalıklı olacakları mesajı verilmişti. ${ }^{69}$ Siyaset bu şekilde kendini güvenceye almıştı ancak, İsrail'in demokratik yapısının temelinde yer alan şahin-dindarlar ve güvercin-laikler arasındaki denge de şahin-dindarlar lehine bozulmuştur. ${ }^{70}$

\section{1996 Seçimleri ve Likud'un Zaferi}

İşçi Partisinin 1992 y1lındaki bariz zaferinden sonra, 1995 y1lındaki Rabin suikastının gölgesinde geçen 1996 seçimlerinde Likud birinci parti olmasa da İşçi Partisinin ardından ikinci parti gelerek 32 sandalye kazanması, 1977

\footnotetext{
64 Israel Shahak, Norton Mezvinsky, a.g.e., s.172-173

65 Ibid, s. 174

66 Abraham Diskin, The Last Days In Israel Understanding the New Israeli Democracy, Frank Cass, London, 2003, s.69

67 Clive Jones-Emma C.Murphy,a.g.e., s.48

68 Ibid, s.75

69 Ibid, s.76

70 Yochanan Peres, a.g.e., s.30
} 
yılındaki tecrübeden sonra Likud için en önemli gelişme olarak kabul edilmektedir. Bu seçimde, diğer sağcı-dinci hatta radikal partilerin de oylarını arttırarak 120 sandalyeli İsrail Parlamentosunda çoğunluğu sağlamaları, İşçi Partisinin birinci parti olmasına rağmen hükümeti kuramamasına yol açmıştır. Böylece, 32 sandalyeye sahip olan Likud ittifakı ve diğer sağc1 partilerden sağlanan 36 sandalye ile toplam 68 milletvekilinden oluşan "ulusal birlik" hükümeti kurulmuştur. ${ }^{11}$

1996 seçimlerinde Likud'un liderliğindeki geniş koalisyonda yer alan dini referanslı partilerin üstlendiği; eğitim, din işleri, iş içleri ve iç güvenlik, yerleşimciler gibi görevler sayesinde dini telkin ve propagandalarını uygulama imkanı bulmuşlardır. Bu sayede, İsrail toplumunun kuruluş felsefesinden uzaklaşılarak, dini referansların yoğun olduğu, diğer farklı etnik ve dini gruplara karşı hoşgörüsüz, sadece Yahudiliğin gereklerini öne çıkaran bir yapıya bürünmesine yol açmışlardır. ${ }^{72} \mathrm{Bu}$ yap1 sayesinde, bu tarihten sonra yapılan bütün seçimlerde kendini sağda ve daha da dindar olarak tanımlayan partiler, kendilerine Knesset'te yer bulmuşlar ve bu partilere göre daha özgürlükçü ve eşitlikçi olan partiler ise bir daha çoğunluğu sağlayamamışlardır.

\section{4. İsrail'in Güney Lübnan'dan Çekilmesi ve 2006 Hizbullah Yenilgisi}

İlki 1976 olmak üzere Lübnan'a ve Lübnan siyasetine müdahale eden İsrail'in 1982 y1lında Beyrut'a kadar gelmesi bir bakıma Hizbullah'ın doğmasına sebep olmuştur. İsrail'in 1980 y1lında 1967 'den beri işgal altında tuttuğu Suriye toprağı olan Golan Tepelerini ilhak etmesine paralel Lübnan'ın güneyinde oluşturduğu güvenlik kuşağı sayesinde kendisini Irak ve Suriye'den koruduğunu düşünmesine rağmen bu bölgede İran'ın teşvik ve desteğiyle kurulan Hizbullah İsrail için beklenmedik bir düşman olarak ortaya çıkmıştır. ${ }^{73}$

1985 yılından itibaren tesis edilen güvenlik kuşağına rağmen 2000 yılındaki çekilmeye kadar bu bölgeden atılan Katyusha roketleri ve Hizbullah'ın

\footnotetext{
Abraham Diskin, a.g.e.,s.83

Clive Jones-Emma C.Murphy,a.g.e., s.33

Dalia Dassa Kaye, "The Israeli Decision to Withdraw from Southern Lebanon: Political Leadership and Security Policy”, Political Science Quarterly, Winter 2002/2003, 117(4), 561-585
} 
vur-kaç saldırıları sebebiyle 256 İsrail askerinin ölmesi ve 840'ının da yaralanması sebebiyle İsrail kamuoyunda başlayan tartışmalar çekilmeye zemin hazırlamıştır. ${ }^{74} 1997$ yılında bölgeye takviye asker götüren iki helikopterin çarpışması sonucu 73 askerin ölmesi sonrasında, ölen askerlerin annelerinin başlatmış olduğu "Dört Anne Hareketi" isimli protesto inisiyatifinin de etkisiyle çekilme siyasetçilerin de gündemine girmiştir. ${ }^{75} \mathrm{Bu}$ bölgedeki askeri varlığın maliyetinin yıllık 300 milyon dolar gibi yüksek seviyelere gelmesi çekilmenin toplum nezdinde daha rasyonel bir davranış olarak görülmesine katkı sağlamıştır ancak sonrasındaki tartışmalara mani olamamıştır.

Lübnan'dan çekilmek zorunda kalmak İsrail toplumunda Sina ve bir sonraki bölümde anlatılacak olan Gazze'den çekilmek gibi ağır bir hasar oluşturmasa da İsrail ordusunun da yenilebileceği kanaatinin oluşması açısından önemli bir hadise olarak kabul edilebilir. Hatta İsrail'in Güney Lübnan'1 işgalini ABD'nin Vietnam macerasına benzeten yakıştırmalar da mevcuttur. ${ }^{76}$ Çekilmeyi haklı k1lan pek çok faktöre rağmen İsrail'in Güney Lübnan'dan çekilmesini; bu bölgedeki askeri varlığı desteklemek maksadıyla bölgedeki Dürzi milislerden oluşturulan Güney Lübnan Ordusunun yüz üstü bırakılması nedeniyle eleştirenler de olmuştur. Zira, 15 yıl boyunca müttefik olarak görülen Güney Lübnan Ordusu, İsrail'in çekilmesiyle karş1 karşıya kaldığı Lübnan toplumu tarafından hain olarak algılanmıştır. Dolayısıyla bu örnek üzerinden gelecekte bölgede müttefik veya ortak bulmak zorlaşmıştır. ${ }^{77}$ Ayrıca çekilmenin tek taraflı bir tasarruf olsa bile İsrail'in caydırıcılığına büyük darbe vurduğu da yadsınamaz bir hakikattir. ${ }^{78}$

Suriye ile muhtemel bir anlaşma ihtimalini mümkün kılabilmek için İsrail'in bölgeden tek taraflı olarak çekilmesinden sonra yaşananlar İsrail yönetiminin planladığı şekilde gelişmemiştir. Aksine, Suriye ile başlayan görüşmeler tıkanmış ve İran'ın desteklediği Hizbullah Lübnan siyasetinde daha etkili bir pozisyona gelmiştir. Küçük çaplı çatışmalarla geçen altı yılın

74 Gal Luft, "Israel's Security Zone in Lebanon-A Tragedy?", Middle East Qurterly, September 2000, s:13-20

75 Dalia Dassa Kaye, a.g.e.

76 Daniel Pipes, "Lebanon Turns into Israel's Vietnam”, Wall Street Journal, 10 Mart 1999

77 Reuven Erlich, "Israel's Unilateral Withdrawals from Lebanon and Gaza Strip: A Comparative Overwiew", Military and Strategic Affairs, Volume3, No.1, May1s 2011,s:61-73

78 Avraham Sela, "Civil Society, the Military, and National Security: The Case of Israel's Security Zone in South Lebanon”, Israel Studies, Volume 12, Number 1,s:53-78 
sonunda 2006 y1lına gelindiğinde ise, İsrail ordusu ve Hizbullah güçleri arasında cereyan eden çatışmalarda da İsrail'in Hizbullah'a yönelik üstünlük sağlayamaması ve tarihindeki en büyük kayıpları vermesi İsrail ordusunun imajını zedelemiştir. ${ }^{79}$

Arap ülkelerinin düzenli ordularına hiç mağlup olmayan ve her savaşta topraklarını genişleten İsrail'in hem de karşısında düzenli bir ordu olmamasına rağmen üstünlük sağlayamaması ve bölgeden çekilmek zorunda kalması İsrail ordusunun yenilmezlik mitini tarihe gömmüştür. İsrail'in 2000 y1lında bölgeden çekilmesinin yegane faktörü olan Hizbullah, İsrail'e ilk yenilgisini tattıran aktör olarak tarih sayfalarında yerini almıştır. ${ }^{80}$ Hizbullah'ın bu galibiyetinin ardından İsrail'e karşı direnme motivasyonu artmış olan Hamas da Gazze'deki varlığını pekiştirmiştir. Hem kuzeyde hem de güneyde İsrail'in varlığına yönelik tehdit oluşturan örgütlerin varlığı İsrail'de daha yoğun güvenlikçi politikaların uygulanmasına imkan tanımıştır. İsrail'in etkili olamadığı bölgelerden firlatılan roketler sayesinde güvenlik kaygıları artan İsrail toplumunda güvenlik politikalarının uygulanmasına yönelik zimni bir destek ortaya çıkmıştır.

\section{Gazze'den Çekilme}

Sharon'un kişisel inisiyatifi ile Oslo anlaşmasındaki hükümlerin aksine uygulamaya konulan Gazze'den tek taraflı olarak çekilme girişimi kendi içerisinde çelişkileri barındırmaktadır. Çünkü barış veya müzakere için bir muhatap olmadığı mesajı veren bu adım sonrasında Gazze'de bir Filistin varlığına göz yumulduğu izlenimi doğsa da Filistinlilerin mevcudiyetinin İsrail'in lütfuna mazhar olduğu görüşü hakim olmuştur. ${ }^{81}$ Bir anlamda Oslo'yu bitiren girişim olarak tanımlanmakla birlikte Filistinlilere kendi bölgelerinde özerk bir yönetim kurma şansı vermesi açısından da önem arz etmektedir. ${ }^{82}$ Ehud Barak'ın 2000 yılında Lübnan'dan çekilirken karşılaştığ dirence benzer bir tepkiyle karşılaşan Sharon, bu tepkiyi Gazze'den çıkarılanlara Batı Şeria'da daha fazla yerleşim yeri açarak azaltmıştır.

79 Eyal Zisser," Hizballah and Israel: Strategic Threat on the Northern Border", Israel Affairs, Vol.12, No.1, Ocak 2006, pp.86-106

80 Eyal Zisser," Is Anyone Afraid of Israel?", Middle East Quarterly, Bahar 2001, pp. 3-10

81 Geoffrey Levin, "One step forward or two steps back? Unilateralism and Israel's Gaza disengagement in the eyes of the World", Israel Affairs, 2014, Vol. 20, No. 1, 87-103

82 Brandon Hollinder," The Israeli Disengagement Plan: Unilateralism in the Face of Multilateral Agreements", Human Rights Brief, 2005, 13.1: 5 
Başta muhafazakar Yahudiler için kabul edilebilir olarak görülmeyen Gazze'den çekilmenin yarattığı travma Sina'dan çekilme kadar olmasa da belirli düzeyde karşılık bulmuştur. Ancak bu bölgeden tahliye edilen Yahudi nüfusun az sayıda olması tepkinin boyutunu da sınırlı kılmıştır. ${ }^{83}$ Kaldı ki Sharon'un siyasal kimliği de bu hamlenin Yahudilerin aleyhine bir girişim olma ihtimalini zayıflatması ve Sharon'un çekilme sonrası yaşadığı sağlık sorunları nedeniyle siyasal hayattan çekilmesi "vaat edilmiş topraklardan" olan Gazze'den çekilmenin etkisini ziyadesiyle azaltmıştır. ${ }^{84}$ Yoğun güvenlik tedbirleri altında yapılan tahliyelerde birkaç ufak direnişle karşılaşılsa da Sina'dan çekilmeye benzer şiddet görüntüleri yaşanmamıştır. Ancak yine de 1967 'den itibaren bölgede konuşlandırılan yerleşimcilerin zorla tahliyesi diğer Yahudi yerleşimcilerde tedirginliğe sebep olmuştur. Zira Filistinliler ile yapılacak muhtemel bir barış sonrası yerleştikleri topraklardan çıkarılma korkusu Gazze'nin tahliyesinden sonra daha yakın bir ihtimal olarak ortaya çıkmıştır.

Süregelen çatışmalardan bıkan İsrail toplumu için Gazze'den çekilmenin bu bölgelerden yapılabilecek saldırıların azalmasını sağlayacağına dair bir beklenti bulunmamakta idi. Aksine, kontrol dışında kalacak bu bölgelerde Hamas, İslami Cihad ve Hizbullah yapılanmalarının artacağı ve barış̧̧ıl Filistinlileri dahi etki altında bırakarak çatışma halinin devam edeceğine olan kanaat daha ağır basmaktaydı. Kaldı ki 2006 yılında yapılan seçimlerde Hamas'ın galip gelerek Gazze'yi yönetmeye başlaması en kötü senaryoyu mümkün k1lmıştır. ${ }^{85}$ Fakat Batı Şeria'daki Mahmud Abbas liderliğindeki Filistin Özerk Yönetimine istinaden daha radikal olan Hamas'1n İsrail'i tanımaması ve müzakereyi kabul etmemesi İsrail hükümetleri tarafindan uluslararası arenada koz olarak kullanılmıştır. Yine de sonraki yı1larda İsrail ordusu tarafından, Gazze'den yapıldığ iddia edilen roketli saldırılara cevaben yapılan saldırılar hem iki toplum arasındaki mesafeyi daha da açmış hem de İsrail'i uluslararası arenada zor durumda bırakmıştır.

İsrail'in Gazze'deki fiili işgalini sonlandırması İsrail toplumundan ziyade Filistinliler üzerinde etkili olmuştur. Zira Gazze'de bir siyasi aktör olarak

83 Ben Thein, Learning from Past Experience: Sinai to Gaza, The Washington Institute for Near East Policy, PolicyWatch 458, 25 Mayıs 2004

${ }^{84}$ Ariel Sharon'un siyasal kimliği ve İsral toplumu için ne ifade ettiğinin anlaşılması için bakınız, Yael S. Aronoff, "Ariel Sharon: From Warfare to Withdrawal”, The Political Psychology of Israeli Prime Ministers, Cambridge,2014, s:78-99

85 Reuven Erlich, a.g.e. 
ortaya çıkan Hamas ile FKÖ arasında yetki paylaşımı krizi yaşanmaya başlamış ve yapılan seçimlerde Hamas'ın mutlak üstünlüğü sonucunda Hamas'ın karşısında başarı sağlamayan FKÖ’yü İsrail'e yaklaştırmıştır. Böylelikle Batı Şeria'ya görece daha küçük bir topraktan vazgeçen İsrail, bunun karş1lığında Filistinlilerin ikiye bölünmesini sağlamış ve uluslararası kamuoyu tarafından terör örgütü olarak tanınan Hamas'1 izole ederek FKÖ ile yaptığı işbirliği sayesinde genel politikalarını sürdürmüştür. ${ }^{86}$ Hamas'ın muhtelif zorluklara rağmen iktidar olduğu Gazze'ye müdahale için hiçbir fırsatı kaçırmayan İsrail aslına bakılırsa Filistinlilere bıraktığını ileri sürdügü bu toprak parçasından elini hiç çekmemiştir.

\section{Sonuç}

İsrail Devleti, 1948 tarihli kuruluş bildirgesinde, dönemine göre ileri say1labilecek; inanç, ırk yada cinsiyet ayrımı yapılmaksızın bütün yurttaşlara toplumsal ve politik hak eşitliği sağlanması, vicdan, inanç, eğitim ve kültür özgürlüğünün eksiksiz biçimde garanti altına alınması gibi maddeleri içeren bir vizyon sergileyerek uluslararası toplumun kendisini kabul etmesini sağlamıştır. ${ }^{87}$ İngiliz Manda yönetiminden bakiye kalan yönetim anlayışının da tesiriyle seküler bir özellik arz eden yeni devletin bir Yahudi devleti olacağ1 vurgulanmış ancak dini atıflar yapılmamıştır. Aksine, Siyonizmin kökenindeki sosyalist damar sayesinde bundan özellikle uzak durulmuştur.

Ancak, zaman içerisinde sahip olunan toprakların miktarının artması ve yeni kazanılan alanlara ekseriyetle Rusya veya Afrika kökenli Yahudilerin yerleştirilmeleriyle, sonradan gelenler ile devletin kurucusu olan kesimler arasında kültür ve bakış farkı oluşmuştur. Özellikle, yeni yerleşim bölgelerindeki meşakkatli yaşam koşulları ve maruz kalınan ekonomik zorluklar toplumu militarize etmiştir. Artan güvenlik kaygıları, bunu kullanmaktan imtina etmeyen radikal örgütlerce istismar edilmeye başlanmıştır. Siyasi liderlerin toplumdaki bu farklılaşma ve kamplaşmadan fayda sağlamak için, iç ve dış gelişmeleri de bahane yaparak kuruluş felsefesinden uzaklaştırmaları İsrail Devletini başka bir noktaya savurmuştur.

Politikacılar ve din adamları, tabanlarını genişletmek ve siyasi fayda sağ-

86 Elisha Efrat, The West Bank and Gaza Strip: A Geography of Occupation and Disengagement, Routledge, NY, 2006, s:166-195

87 Şloma Sand, Yahudi Halkı Nasıl İcat Edildi Kitabı Mukaddes'ten Siyonizme, DK, İstanbul, 2011, s.344 
lamak maksadıyla, Filistin halkının mücadelesini ve İran'lı yöneticilerin kendilerini hedef alan sözlerini de kullanarak, toplumu dönüştürmek için apokaliptik söylemlere de başvurmuşlardır. Dini enstrümanların kullanımı etkiyi artırsa da zamanla bu kurgu söylemden çıkıp pratiğe dökülmüş ve İsrail'in Yahudi kimliği ön plana çıkmıştır. İsrail toplumunun sürgün, göç, diaspora, holokost, seçilmiş ırk, vaat edilmiş topraklar gibi sosyolojik ve dinsel terminolojinin harmanlandığ yapısına sonradan enjekte edilen çok kültürlülük, çok dinlilik, eşitlik, özgürlük, hoşgörü gibi kavramlar maalesef yeterince içselleştirilememiştir.

Dolayısıyla, toplumun en zayıf noktası olan dini hassasiyetler kullanılarak, Arap-İsrail savaşlarından başlayıp, 1977 seçimleriyle kendini hissettirmeye başlayan radikalizm 1995 yılındaki Rabin suikastı ile doruğa çıkmıştır. 1996 yılındaki seçimlerden sağcı Likud Partisinin galibiyetle çıkması aslında sadece bu sürecin sonucudur. Çünkü önceki gelişmeler İsrail toplumunu yavaş yavaş bu noktaya getirmiş ve toplum yeniden inşa edilmiştir. Günümüzde İsrail ekseninde yaşanan gelişmelerde de aynı sosyal inşanın etkisini görmek mümkündür. Zira 2000 yılında ABD Başkanı Clinton'ın kişisel çabaları ve büyük umutlar ile başlayan İsrail-Filistin barış görüşmeleri, kuruluş felsefesinin aksine üretilen yeni dilin gereği olarak İsrail' in çözümsüzlük politikasında diretmesi nedeniyle akamete uğramıştır. Topluma ve siyasete yerleşen dini ögretiler ve bu öğretilerin müsamahasız buyrukları nedeniyle, işgal altındaki toprakları kendilerine vaat edilmiş topraklar olarak gören ve iadesini ret eden ayrıca bu topraklarda farklı bir din, dil ve 1rk1 istemeyen bir anlayışın, "barış", "özgürlük", "eşitlik", "sayg1 ve hoşgörü” gibi kavramları sahiplenmeleri beklenemez.

\section{Kaynakça}

Abraham Diskin, The Last Days In Israel Understanding the New Israeli Democracy, Frank Cass, London, 2003

Anthony Giddens, The Constitution of Society: Outline of the Theory of Structuration, Berkeley: University of California Press, 1984

Avraham Sela, "Civil Society, the Military, and National Security: The Case of Israel's Security Zone in South Lebanon", Israel Studies, Volume 12, Number 1 
Barry Buzan, Ole Wæver, Jaap de Wilde, Securitiy: A New Framework for Analysis, London: Lynne Rienner Publishers, 1998

Ben Thein, Learning from Past Experience: Sinai to Gaza, The Washington Institute for Near East Policy, PolicyWatch 458, 25 May1s 2004

Bernard Hourcade, "Iran Facing Israel", The World Facing Israel-Israel Facing the World, Images and Politics, Alfred Wittstock (ed.), Berlin, 2011

Bora Bayraktar, Oslo Barış Süreci İsrail-Filistin Barlş Görüşmeleri, 19912000, Küre, İstanbul, 2013

Brandon Hollinder, "The Israeli Disengagement Plan: Unilateralism in the Face of Multilateral Agreements", Human Rights Brief, 2005, 13.1: 5

Burcu Güçlü Akpınar, “Arap-İsrail Savaşlarının Etkileri”, Ortadoğu Analizi İki Kutuplu Sistem Sonrası Ortadoğu ve Arap Baharı, Hasret Çomak, Caner Sancaktar (ed.), Beta, İstanbul, 2014

Bülent Aras, Filistin-İsrail Barlş Süreci ve Türkiye, Bağlam, İstanbul, 1997

Christian Reus-Smith, Constructism, Scott Burchill (ed.), Theories of International Relations, Palgrave Macmillan, Basingstoke, 2009

Clive Jones-Emma C.Murphy, Israel Challenges to Identity, Democracy and The State, Routledge, London, 2002

Dalia Dassa Kaye, "The Israeli Decision to Withdraw from Southern Lebanon: Political Leadership and Security Policy", Political Science Quarterly, Winter 2002/2003, 117(4)

Daniel Pipes, “Lebanon Turns into Israel's Vietnam”, Wall Street Journal, 10 Mart 1999

David Menashr1,Iran,Israel and the Middle East Conflict, Israel Affairs, 2006,12:1

Donald J. Puchala (Der.), Visions of International Relations, Columbia: University of South Carolina Press, 2002

Davut Ateş, "Uluslararası İlişkilerde Konstrüktivizm: Ortayol Yaklaşımının 
Epistemolojik Çerçevesi”, Sosyal Bilimler Dergisi, Cilt:X, Sayı:1, Haziran 2008

Derek J. Penslar, Israel in History The Jewish State in Comparative Perspective, Routledge, NY, 2007

Efraim Inbar, Israel's National Security, Issues and Challenges Since The Yom Kippur War, Routledge, NY,2008

Eliezer Ben-Rafael, Yochanan Peres, Is Israel One? Religion, Nationalism and Multiculturralism Confounded, Brill, Lieden, 2005

Elisha Efrat, The West Bank and Gaza Strip : A Geography of Occupation and Disengagement, Routledge, NY, 2006

Eyal Zisser," Is Anyone Afraid of Israel?", Middle East Quarterly, Bahar 2001

Eyal Zisser," Hizballah and Israel: Strategic Threat on the Northern Border", Israel Affairs, Vol.12, No.1, Ocak 2006

Fatma Aslı Kelkitli," İdealizm ve Realizm Sarkacında Soğuk Savaş Sonrası İran Dış Politikası", Ortadoğu Analizi İki Kutuplu Sistem Sonrası Ortadoğu ve Arap Baharı, (ed.) Hasret Çomak-Caner Sancaktar, Beta, İstanbul, 2014

Gal Luft, "Israel's Security Zone in Lebanon-A Tragedy?", Middle East Qurterly, September 2000

Geoffrey Levin, "One Step Forward or Two Steps Back? Unilateralism and Israel's Gaza Disengagement in the Eyes of the World", Israel Affairs, 2014, Vol. 20, No. 1

Gerald Cromer, A war of Words: Political Violence and Public Debate in Israel, Frank Cass, 2004

Henning Boekle,Volker Rittberger ve Wolfgang Wagner, "Norms and Foreign Policy: Constructivist Foreign Policy Theory", German Foreign Policy Since UnificationTheories and Case Studies, Volker Ritteberger (ed.), Manchester University Press, 2001

Israel Shahak, Norton Mezvinsky, İsrail'de Yahudi Fundamentalizmi, çev. 
Ahmet Emin Dağ, Anka, İstanbul, 2004

Jerold S. Averbach, Jewish State Pariah Nation Israel and the Dilemmas of Legitimacy, Quid Pre Books, New Orleans,2014 (e book)

John Ruggie, Constructing the World Polity: Essays on International Institutionalization, London, Routledge 1998

Jonathan Mendilow, Ideology, Party Change and Electrol Campaigns in Israel, 1965-2001, State University on NY, 2003

Mustafa Küçük, "Uluslararası İlişkilerde 'Konstrüktivist Dönüşü' Anlamak”, Ege Akademik Bakış, Cilt:9, Sayı:2, 2009

Nicholas Onuf, "World of Our Making: The Strange Career of Constructivism in International Relations", Donald J. Puchala (Der.), Visions of International Relations, Columbia University of South Carolina Press, 2002

Nicholas Onuf, World of Our Making: Rules and Rule in Social Theory and International Relations, Columbia University of South Carolina Press, 1989

Nuri Yurdusev, “Avrupa Kimliğinin Oluşumu ve Türk Kimliği”, Atilla Eralp (Der.), Türkiye ve Avrupa: Batılılaşma, Kalkınma, Demokrasi, Ankara: İmge Kitabevi, 1997

Reuven Erlich, "Israel's Unilateral Withdrawals from Lebanon and Gaza Strip: A Comparative Overwiew", Military and Strategic Affairs, Volume 3, No.1, May1s 2011

Richard Ashley, "The Poverty of Neorealism", Robert Keohane (Ed.), Neorealism and Its Critics, New York: Columbia University Press

Richard Pierce ve Christian Reus-Smit, "Critical International Theory and Constructivism", European Journal of International Relations, Cilt:4, Say1:3, 1998

Ronald L. Jepperson, Alexander Wendt ve Peter J. Katzenstein, "Norms, Identity, and Culture in National Security", Katzenstein J. Peter (ed.), The Culture of National Security: Norms, and Identity in World Politics, Columbia University Pres, New York, 1996 
Shlomo Swirski, "The Burden of Occupation, The Cost of the Occupation to Israeli Society, Polity and Economy", Adva Center, Center of Information on Equality and Social Justice in Israel, 2008

Şloma Sand, Yahudi Halkı Nasıl İcat Edildi Kitabı Mukaddes 'ten Siyonizme, DK, İstanbul, 2011

Tayyar Arı, Geçmişten Günümüze Ortadoğu Siyaset, Savaş ve Diplomasi, MKM, Bursa, 2012 (5. Bask1)

Victor Kattan, From Coexistence to Conquest, International Law and the Origin of the Arab-Israeli Conflict 1891-1949, PlutoPress,2009

Wendt, "Collective Identity Dormation and The International State", The American Political Science Review Vol. 88, No. 2, 1994

Wendt, "Constructing International Politics", International Security, 20: 1, Summer 1995

Wendth Alexander, Anarchy is What States Make of it: The Social Construction of Power Politics, International Organization, Vol. 46, No. 2. Spring, 1992

Wendth Alexander, Social Theory of International Relations, Cambridge University Press, 1999

William L. Cleveland, Modern Ortadoğu Tarihi, Agora, İstanbul, 2008

Yael S. Aronoff, "Ariel Sharon: From Warfare to Withdrawal”, The Political Psychology of Israeli Prime Ministers, Cambridge,2014

Yochanan Peres,'Internal Constraints On The Arab-Israeli Peace Process: An Israeli View", Palestine Jordan Israel Building a Base for Common Scholarship and Understanding in the New Era of the Middle East, PASSIA, Kudüs, 1997 